\title{
Stakeholder Governance as a Response to Wicked Issues
}

\author{
Sybille Sachs $\cdot$ Edwin Rühli $\cdot$ Claude Meier
}

Published online: 28 June 2011

(C) Springer Science+Business Media B.V. 2011

Keywords Stakeholder network - Mutual value creation . Global governance $\cdot$ Wicked issues $\cdot$ Enlarged property right understanding

\section{Introduction}

The rising defaults on subprime mortgages in the US triggered a global crisis for the money markets. Many of the world's leading investment banks have collapsed as a result and the US government has proposed a massive bailout. Similar observations can be made for the UK, Europe and Asia. Other sectors of the economy are also suffering, and the crisis has had a strong impact on the society at large. The situation has become not only an economic but also a societal challenge.

In this context, we are increasingly confronted with issues which have effects beyond the borders of nation states, and which include business as well as political and societal institutions of all kinds. Such problems are called "wicked issues", because they involve many stakeholders with different values and priorities, and cannot be solved or even dominated by one institution or sector alone (Camillus 2008). The current global financial crisis is such a problem. It has become one of the most radical reformations of the global banking sector ever, and it

S. Sachs $(\bowtie) \cdot$ C. Meier

University of Applied Sciences in Business

Administration Zurich, Zurich, Switzerland

e-mail: Sybille.Sachs@fhhwz.ch

E. Rühli

University of Zurich, Zurich, Switzerland fundamentally impacts our understanding of successful governance systems.

None of the actors in the political or economic systems seems particularly well coordinated, either within themselves or among each other. Hence, there is not any overall scheme of coordinated governance. Therefore, no solution that affects stakeholders satisfactorily regarding this issue can be dismissed out of hand. The call for better governance systems also comes from experts in the financial sector itself, as a letter from former hedge fund manager Lahde (2008) demonstrates: "My suggestion is that [...] great minds $[\ldots]$ come together [in a forum] to create a new system of government [...]." Establishing adequate governance systems is still a long way away. However, it is evident that neither the nation states nor private organizations such as corporations, NGOs and others will be able to solve this wicked global problem on their own.

In accordance to the above, we will focus on what follows the deficient coordination and cooperation between different governance approaches (political and economic) from a stakeholder perspective. In this article, we are aiming at extending "Stakeholderism" from the traditional level of business to a new field, which we call "Stakeholder Governance". We will reflect on how different stakeholders can address wicked issues with a global scope, and what the resulting demands on the governance systems are. The focus is on global issues that are sufficiently far-reaching to permeate different economic and political systems, and on mutual value creation in relation to these issues. Therefore, we see a need to explore the impact of organizational networks such as stakeholder networks and the actors involved at different levels. There is no consistent terminology in the literature concerning multi-stakeholder approaches (e.g., networked governance; multi-sectoral networks). Our preferred term for the phenomenon is 
stakeholder network, from which we will begin to develop the concept of stakeholder governance. In order to develop an appropriate governance system for the situations described above, we will first concentrate on the characteristics of the current economic and the political governance systems.

\section{Governance Systems from an Economic Perspective}

Based on the thinking of Friedman (1970), the principles of the market as coordinator and the belief in its problem solving capacities seem to be omnipresent today (Freeman et al. 2007, 2010). Therefore, the actors in the market claim that self-regulation is the key to supplement free competition in the markets, as demonstrated by several types of codes of conduct, created by themselves or business associations (see e.g., King and Lenox 2000). None of these codes includes any sanction mechanisms. With such codes of self-regulation, corporations try to solve problems regarding certain issues on their own, without involving actors from other sectors, especially not influences from the state. We are experiencing a time that is strongly influenced by such an economic paradigm, and this paradigm is increasingly being applied to all spheres of social life (Freeman et al. 2007, 2010). From this perspective, our main focus is on the firm and the firm's governing system.

In the market-economic theory of the firm, different streams of research have been developed, such as the Principal Agency Theory (Fama and Jensen 1983; Jensen and Meckling 1976), the transaction cost theory (see e.g., Coase 1937; Williamson 1989), or the property rights theory (see e.g., Alchian and Demsetz 1972; Hart and Moore 2000) to explain why firms exist and how firms perform successfully (for an overview see e.g., Cyert and March 1992; Foss 2000; Milgrom and Roberts 1992). These theories have influenced the field of strategic management, and therefore also the understanding of corporate governance. Blair and Stout (1999) call this the "Grand Design of the Principal Agent Model", where the owner, in a public corporation represented by the shareholders, is the ultimate instance of control in the firm, due to the assumption that the shareholders are the sole claimants of residual risk.

In contrast to this traditional approach and from a property rights perspective of the firm (e.g., Alchian and Demsetz 1972; Asher et al. 2005; Blair 2005; Blair and Stout 1999; Wang et al. 2009), scholars increasingly doubt that the dominance of the owner is the most effective way to understand strategic management. In the same vein, Stout $(2007$, p. 9) writes: "Not too long ago, it was conventional economic wisdom that the shareholders in a corporation were the sole residual claimants in the firm, meaning shareholders were entitled to all the 'residual' profits left over after the firm had met its fixed contractual obligations to employees, customers, and creditors. This assumption suggested that corporations were run best when they were run for shareholders' benefit alone, because if other corporate stakeholders' interests were fixed by their contracts, maximizing the shareholders' residual meant maximizing the total social value of the firm. Time has been unkind to this perspective. Advances in economic thinking have made clear that shareholders generally are not - and probably cannot be - sole residual claimants in firms." Blair and Stout (1999) also claim to have rethought the ownership approach by focusing more on the importance of intellectual capital. In this perspective, the corporation is only legitimized in its existence and only fulfills its responsibilities, if it creates wealth for and with its stakeholders. These arguments imply that corporate responsibilities should integrate both wealth creation and wealth dissemination (Phillips et al. 2003, p. 487): "Stakeholder theory is concerned with who has input in decision making as well as with who benefits from the outcome of such decisions." This stakeholder perspective challenges the understanding of traditional capitalism. Property rights are not only attributed to shareholders but also to owners of intellectual capital or more generally to constituents making firm specific investments. In the same vein, Stiglitz (2006, p. 203) proposes in his book on globalization a reorientation of the firm's role in society, and that this could lead to better solutions of important global issues: "One step in the right direction (note of the author: to improve corporate governance) would be to have companies take into account all stakeholders - employees and the communities in which they operate, not just their shareholders." This is especially challenging for MultiNational Corporations (MNC) that are active in different societal settings. However, this new corporate role has neither been thoroughly defined in regard to the state and civil society, nor has it been legitimized through a democratic process (Matten and Crane 2005).

The essence of government in the economic system (see Fig. 1 below) is, therefore, market regulation, sometimes additionally disciplined by soft laws and corporate governance in a traditional "Grand Design" or a newly discussed Stakeholder Model. On the basis of this frame of reference, firms address global wicked issues.

\section{Governance System from a Political Perspective}

In contrast to the market mechanisms, the political system is a strongly hierarchical system with a monopoly of power by nation state governments, which have the possibility to sanction due to regulations. Two important roles of 
Fig. 1 Stakeholder governance

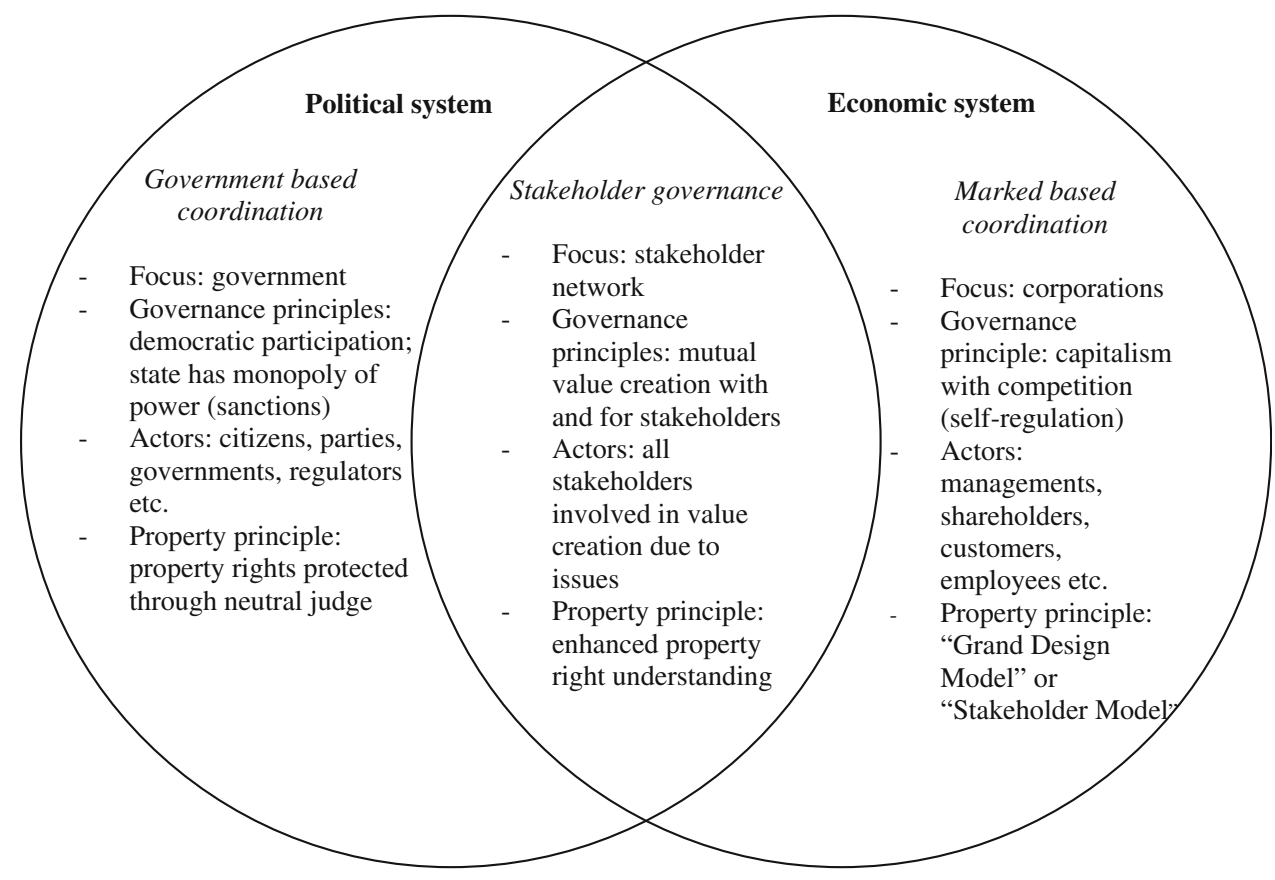

Western democracies are firstly, the protection of property against illegal acquisition (through neutral judgements and threat of sanctions) and secondly, providing public goods (e.g., in the form of the welfare state). Most approaches in the political sciences are state-centric. State actors and institutions (e.g., parliament, government, public authorities, policy programs) are the center of interest not only in fields like comparative political science, but also international relations where all kinds of relations between states (e.g., balance of power, interdependence, installation of regimes like WTO) are investigated and explained (see e.g., Immergut 1992; Keohane and Nye 1977; Morgenthau 1948; Waltz 1979). Hence, nation state actors are seen as the most relevant actors (see Fig. 1 below).

Today, however, a new and modern political science view in international relations, such as the concept of global governance, has given up this rigorous state-centrism (see Abbott and Snidal 2009; Dingwerth and Pattberg 2006a, p. 187f., 2006b, p. 378f.; Messner and Nuescheler 2003; Rasche 2008; Reinicke 1997, p. 132). We have a better understanding of a system of cooperative global governance thanks to scholars (Abbott and Snidal 2009; Benner et al. 2004; Brütsch and Lehmkuhl 2007; Dingwerth and Pattberg 2006a; Held 2004; Reinicke 1997), who question the strong dominance of governments of nation states and intergovernmental organizations as the sole relevant actors in regulation politics in transnational policy fields. Rosenau (1995, p. 13) defines the term as follows: "Global governance is conceived to include systems of rule at all levels of human activity - from the family to the international organization - in which the pursuit of goals through the exercise of control has transnational repercussions." Hence, the two main characteristics of the concept are firstly, the relevance of different actors in international relations, namely state and non-state actors; and secondly, systems of rule from the local to the global level. In relation to rules, a governance system can be defined as "creating the conditions for ordered rule and collective action" (Stoker 1998, p. 18).

In the global governance approach, all relevant actors concerning an issue-including state actors, MNCs and civil society - can similar to the modern theory of the firm be seen as stakeholders (see e.g., Benedek 2006, p. 267, 2007; Benner et al. 2004, p. 194). To bring together all relevant stakeholders, stakeholder networks are needed. According to Kaul et al. (2003, p. 31) in recent years, the policy agenda has lengthened and issues have become more complex on the global level. Held (2004) proposes a global issue network (GIN), i.e., a distinct global issue network for each urgent policy problem (e.g., world health, global economic regulation, energy) that brings together the different stakeholders (see also Dingwerth and Pattberg 2006a, b, p. 383; Held 2004, p. 104ff.). According to Held (2004) in an issue network, an affected stakeholder (e.g., neighborhood of a chemical industry) is brought together with decision-maker stakeholders (e.g., management of MNC), and hence both have a say in the assignation of this issue. Thus, all relevant stakeholders would have a say in providing a global public good (or in solving an issue) of decisive importance for themselves (Held 2004, p. 79ff.; Rondinelli 2002, p. 391ff.; Wolf 2000; 2003, p. 234ff.). In an empirical study, Fransen and Kolk (2007) compare what 
they call multi-stakeholder standards to other collaborative standards (these are drawn by single actors such as NGOs, or International Governmental Organizations (IGOs) such as UN, WTO or by business associations) concerning the dimensions of membership, governance and implementation. In their conclusion, they state that "multi-stakeholder standards appear to have qualities that make them preferable over other collaborative standards" (Fransen and Kolk 2007, p. 678). Cerny (2000), for example, emphasizes the existence of diffuse and complex transnational webs of governance. In his eyes, the formation of transnational interest groups and the development of trans-governmental coalitions are bringing different actors together into regular networks, cutting across splintered states (Cerny 2000, p. 173). Hence such networks cut across established political and industrial borders. Also Midttun (2007) advocates an arena of partnered governance between political and economic areas due to the challenges of global issues.

Benner et al. (2004, p. 193) note in summary: "New forms of 'networked governance' at the intersection of the public, private and not-for-profit sectors reflect the transformation of governance in an increasingly interdependent world." "Networked governance" can create innovative and flexible institutions which expand an organizational vision.

What networked or stakeholder governance cannot do is legislate. Such multi-sectoral or stakeholder networks and new forms of public-private governance usually exist to complement national policy-making and international cooperation (Benner et al. 2004, 195ff.; Rasche 2009). Even if some authors demand more coercive global governance, stakeholder networks have no power to sanction and hence their codes are at best "soft laws" (see e.g., Benedek 2006; Benner et al. 2004, p. 200; King and Lenox 2000). Thus, the main aim of such networks is to create a qualified governance system in an area by bringing together the relevant stakeholders.

\section{An Initial Framework for Stakeholder Governance}

Due to deficient coordination and cooperation between different governance approaches, we advocate a 'Stakeholder View' already mentioned briefly above. The starting point of such a Stakeholder View is the corporation as an economic and simultaneously societal institution embedded in a broad range of stakeholders (Freeman et al. 2010, e.g., Savage et al. 2008; Waddock et al. 2002). The Stakeholder View as developed by Post et al. (2002) emphasizes that the linkages between the corporation and its multiple constituencies in the economic and societal sphere are in many ways important vehicles for creating, sustaining, and enhancing the corporation's wealth-creating capacity.

If corporations want to tap their stakeholder network as a source of corporate success, they need a system and a procedure to build a common ground with their stakeholders (see e.g., Freeman et al. 2007; Savage et al. 2008; Windsor 2008). In this line of thinking, we understand value creation with and for stakeholders as a mutual process, which is not only understood in financial terms, but encompasses a broader understanding of value, the content of which needs to be defined among the parties involved. These stakeholders are linked through networks (e.g., Frankforter and Hill 2008; Roloff 2008; Rowley 1997; Savage et al. 2008). Stakeholder governance takes place within the stakeholder network, in which the concrete global issue to be solved is embedded. Therefore, the stakeholder network seems the appropriate unit of analysis, as it provides a promising starting point to conceptualize research on global wicked issues and new governance systems.

The normative core of the Stakeholder View, as developed in the context of the theory of the firm, is based on the idea of property rights (see Post et al. 2002), as one of the most important principles of our society (e.g., Alchian and Demsetz 1972; Asher et al. 2005; Becker et al. 1978; Blair 1995, 2005; Blair and Stout 1999; Coase 1960). The Stakeholder View of Strategy broadens the idea of property rights not only to a financial view, but also to all those that contribute (voluntarily or non-voluntarily) an issue-specific investment, such as knowledge or cooperation in the stakeholder network. This has in fact important implications for wealth creation and wealth distribution processes, as well as for governance systems and control, by including all stakeholders in the network that are either benefit receivers or providers, as well as risk providers or bearers.

Based on our current research (Sachs et al. 2010, 2011b), we can say that the health care sector is interesting for carrying out such research on stakeholder governance beyond the level of the firm due to the current challenges this sector faces, the many actors involved in the value creation process and the interrelatedness of the relevant stakeholders (Savage et al. 2004). The issues that the pharmaceutical industry, as well as the different national health care systems, are confronted with can be neither resolved by the nation states nor by the corporations alone. Stakeholders such as pharmacists, hospitals, government authorities, professional associations, insurances, regulators and patient advocacy groups are affecting the new market structure and the political decision making processes. These stakeholders are aiming to shift power and the level of influence to the traditional stakeholder networks (see Lehtimäki and Kujala 2004; Schmitt 2007). Top-down initiatives for such issues as for instance the 
"European Platform for Action on Diet, Physical Activity and Health" are often not very efficient, because from the start they assemble all the possible stakeholders according to the interests of the representative nation states and EU. In such processes, stakeholders with impacts on value creation are often neglected, according to our empirical investigations (see Sachs et al. 2010, 2011b).

The global financial crisis has created similar problems. As long as the globally interdependent financial markets were running smoothly, calls for more coordination, regulation and control were moderate. Most stakeholders like investors, regulators (e.g., government), mortgage takers, financial corporations (e.g., banks, hedge funds) and their employees, normal bank clients and a majority of the public were generally content with the value creation in the financial sector. After the previous economic crisis (dotcom bubble), some measures, especially in the field of corporate governance (e.g., codes of conduct; SarbanesOxley-Act), were established, namely concerning wealth creation and distribution through shareholder value maximization. These measures mostly had to be understood in a narrow sense of property rights.

The new financial crisis shows that despite such measures the issue of global financial markets and their stakeholders still was not coordinated sufficiently, and neither was the cooperation between the relevant actors. In the course of the new crisis, many investors have lost their money and employees their job. The demand and supply situation in the 'real economy' with its many small and medium-sized businesses has begun to worsen. Governments from various countries have had to attempt to contain the crisis by spending billions of dollars. In the end, with the financial involvement of the nation states in the financial sector, the public and politicians have become one of the very important stakeholders in the issue. Due to the lack of adequate governance systems, what the former value creation of the financial markets was for some has become a loss of value for many, namely for whole political economies around the globe. Nation state regulatory authorities, whose influence is restricted to state borders, were not in a position to anticipate and avert the crisis. The meetings of heads of state at different financial summits (e.g., G-20) after the outbreak of the crisis with the aim of seeking internationally coordinated action have only been partly successful. It is also questionable if stronger codes of conduct imposed voluntarily by some of the financial corporations will suffice (e.g., manager compensation). None of these state and non-state actors is able to solve such problems alone. Smaller countries are economically too weak to save their financial MNCs several times over (or even once), and the problem of coordination isn't solved by individually implemented corporate governance models in single corporations. Furthermore, it is not enough to strengthen inter-state-built IMF alone, because here again the earlier mentioned problems of topdown approaches will arise, as important stakeholders could be neglected. The examples of the somewhat helpless governance approaches in the financial crisis prove the need for better frameworks for global governance (IMF 2008; New York Times 2008; Spiegel-Online 2008).

Therefore, we claim that the impacts of such issues have to be negotiated from the perception of the different stakeholders based on an enhanced understanding of property rights. Especially those stakeholders who are perceived as most important for the focal issue have firstly to exchange perceptions with each other bilaterally. Then, step-by-step, these discussions have to be coordinated and aligned by a neutral independent authority such as moderation accepted by the involved parties. In this process, there may be a need to include additional stakeholders. In this way, networks for stakeholder governance concerning certain issues can be established.

The following framework (Fig. 1) summaries and emphasizes the contribution of stakeholder governance for global wicked issues:

\section{Challenges of Stakeholder Governance}

One of the main challenges of a governance system based on stakeholder networks is not only bringing in all relevant groups and being effective, but is legitimacy. Such networks are mostly horizontal and deliberative, and are therefore fundamentally different from democracies in a parliamentary sense, where every citizen has at least a vote in the political process (Wolf 2000, 2003, p. 234ff.). In a democratic state, the political agency which gets the majority of votes comes to power legitimately. Such 'vertical' or input legitimacy is very difficult to achieve for the representatives of a global issue-network, in which state and non-state actors participate (Benner et al. 2004, p. 192ff.; Cerny 2000, p. 181).

It is also salient in a stakeholder governance system to clarify the similarities and differences of the term "citizen" in relation to "stakeholder." "Citizen" considers the membership of an individual to a nation state, where he or she has rights (e.g., a vote) and duties (e.g., paying taxes). Stakeholders are usually seen as actors in the role either as benefit receivers/providers or risk bearers/providers toward a firm or toward an issue. The global governance approach thinks of an issue at a network's center, while the stakeholder approach normally thinks of a corporation at the network's center (see e.g., Roloff 2008). Stakeholders may be individuals, communities, organizations or communities (Held 2004, p. 99; Keohane 2002, p. 14ff.). Contrary to the citizen, a stakeholder usually has not the right to participate 
in a democratic decision making process, even if he is strongly affected by an issue or an action. The stakeholder's role in a network to solve wicked global issues differs from the citizen's role in a national state.

An interesting development concerning citizenship and democracy that is flourishing in the area of stakeholder research of firms is the idea of stakeholder democracy. Different streams, most of them influenced by the discourse on 'corporate citizenship', can be singled out. One stream focuses on the discussion of the firm as a global player and thus also a potential owner of global issues. Firms are understood as citizens who have rights and responsibilities toward the community and other stakeholders (Crane et al. 2004; Rondinelli 2002; Waddock and Smith 2000). Another stream stresses primarily the processes of participation on two different levels. On the firm or corporate governance level, the question is how stakeholders are integrated in the managerial decision making process (De Jong and Van Witteloostuijn 2004, e.g., Harrison and Freeman 2004; critical: Kerr 2004; Matten and Crane 2005). On the macro level, questions about corporations participating in governance processes are raised (Palazzo and Scherer 2006; Thompson and Driver 2005). Thus, several authors (e.g., Bäckstrand 2006; Bendell 2005; Kaler 2002; Matten and Crane 2005) at different levels critically discuss the governance systems of stakeholder democracy. These insights contribute to the specificities of a stakeholder governance system.

\section{Avenues of Further Research}

In the emerging "Stakeholder Governance" research, the following areas can be identified as important:

- A multi-level approach seems appropriate for research into governance systems in relation to global wicked issues. We claim that a bottom-up approach would be a more effective procedure in contrast to a top-down approach (see e.g., Habermas 2008 [for the contrary position]; Windsor 2007). This procedure would more easily allow for identifying other newly emerging governance systems.

- There is also a need to elaborate how the process of mutual value creation is defined by the stakeholders involved (Sachs et al., 2011a). Does mutual value creation have to consider both the public and private good (for this discussion see Freeman et al. 2010; Freeman et al. 2007; Held 2004; Kaul et al. 2003; Rondinelli 2002)?

- A reflection on the process of legitimation (as already hinted above) has to take place, namely how do each of the parties involved receive a legitimate status or not by taking into account both democratic and market principles (see e.g., Bendell 2005; Benner et al. 2004; Wolf 2000, 2003). Aligned with this question is a readjusted understanding of the roles of the corporation (Matten and Crane 2005; Post et al. 2002) and the nation state in a modern society (Held 2004).

- There is also the possibility for empirical research (e.g., comparative case analysis) of successful and unsuccessful examples of governance systems tackling wicked issues with global scope.

- Finally, we have to think about whether stakeholder theory has the potential of a meta theory, similar to the claim of biological evolutionary theory by some scholars, based on the application of principles of evolutionary thinking to social or economic science (see e.g., Dawkins 1986; Wilson 1998).

\section{References}

Abbott, K. W., \& Snidal, D. (2009). The governance triangle: Regulatory standards institutions and the shadow of the state. In W. Mattli \& N. Woods (Eds.), The politics of global regulation (pp. 44-88). Princeton: Princeton University Press.

Alchian, A. A., \& Demsetz, H. (1972). Production, information costs, and economic organization. The American Economic Review, 62(5), 777-795.

Asher, C. C., Mahoney, J. M., \& Mahoney, J. T. (2005). Towards a property rights foundation for a stakeholder theory of the firm. Journal of Management and Governance, 9(1), 5-32.

Bäckstrand, K. (2006). Democratizing global environmental governance? Stakeholder democracy after the world summit on sustainable development. European Journal of International Relations, 12(4), 467-498.

Becker, R., Mackenthun, M., \& Müller, R. (1978). Controlling. In G. Kienbaum (Ed.), Strategische Unternehmungsführung pp. München: Verlag Moderne Industrie.

Bendell, J. (2005). In whose name? The accountability of corporate social responsibility. Development in Practice, 15(3\&4), 362-374.

Benedek, W. (2006). Global Governance der Weltwirtschaft. In P. Koller (Ed.), Die globale Frage: Empirische Befunde und ethische Herausforderungen (pp. 257-274). Wien: Passen Verlag.

Benedek, W. (2007). The emerging global civil society: Achievements and prospects. In V. Rittberger \& M. Nettesheim (Eds.), Changing patterns of authority in the global political economy, Vol. II: New actors and forms of regulation (pp. 170-185). Houndsmill: Palgrave Macmillan Publishers.

Benner, T., Reinicke, W. H., \& Witte, J. M. (2004). Multisectoral networks in global governance: Towards a pluralistic system of accountability. Government and Opposition, 39(2), 191-210.

Blair, M. (1995). Ownership and control. Washington: The Brookings Institute.

Blair, M. (2005). Closing the theory gap: How the economic theory of property rights can help bring "stakeholders" back into theories of the firm. Journal of Management and Governance, 9(1), 33-39.

Blair, M. M., \& Stout, L. A. (1999). A team production theory of corporate law. Virginia Law Review, 85(2), 247-328. 
Brütsch, C., \& Lehmkuhl, D. (2007). Law and legalization in transnational relations. In C. Brütsch \& D. Lehmkuhl (Eds.), Complex legalization and the many moves to law (pp. 9-32). London: Routledge.

Camillus, J. C. (2008). Strategy as a wicked problem. Harvard Business Review, 86, 99-106.

Cerny, P. G. (2000). Globalization and the disarticulation of political power: Towards a new middle ages? In H. Goverde, P. G. Cerny, M. Haugaard, \& H. H. Lentner (Eds.), Power in contemporary politics (pp. 170-186). London: Sage Publications.

Coase, R. H. (1937). The nature of the firm. In O. E. Williamson \& S. G. Winter (Eds.), The nature of the firm-oigins evolution and development (pp. 18-33). New York: Oxford University Press.

Coase, R. H. (1960). The problem of social cost. Journal of Law and Economics, 3, 1-44.

Crane, A., Matten, D., \& Moon, J. (2004). Stakeholders as citizens? Rethinking rights, participation, and democracy. Journal of Business Ethics, 53, 107-122.

Cyert, R. M., \& March, J. G. (1992). A behavioral theory of the firm. Oxford: Blackwell.

Dawkins, R. (1986). The blind watchmaker-why the evidence of evolution reveals a universe without design. Bath: Norton Press.

De Jong, G., \& Van Witteloostuijn, A. (2004). Successful corporate democracy: Sustainable cooperation of capital and labor in the Dutch Breman Group. Academy of Management Executive, 18(3), 54-66.

Dingwerth, K., \& Pattberg, P. (2006a). Global governance as a perspective on world politics. Global Governance, 12(2), 185-203.

Dingwerth, K., \& Pattberg, P. (2006b). Was is it global governance? Leviathan, 34(3), 377-399.

Fama, E. F., \& Jensen, M. C. (1983). Separation of ownership and control. Journal of Law and Economics, 26, 301-325.

Foss, N. J. (2000). The theory of the firm: An introduction to themes and contributions. In N. J. Foss (Ed.), The Theory of the Firm (pp. xi-lxi). London: Routledge.

Frankforter, S. A. \& Hill, V. (2008). A model of stakeholder networks: Qualities, relationship and structure. Paper presented at Academy of Management Annual Meeting.

Fransen, L., \& Kolk, A. (2007). Global rule-setting for business: A critical analysis of multi-stakeholder standards. Organization, 14(5), 667-684.

Freeman, R. E., Harrison, J. S., Wicks, A. C., Parmar, B. L., \& De Colle, S. (2010). Stakeholder theory: The state of the art. Cambridge: Cambridge University Press.

Freeman, R. E., Martin, K., \& Parmar, B. (2007). Stakeholder capitalism. Journal of Business Ethics, 74, 303-314.

Friedman, M. (1970). The social responsibility of business is to increase its profits. New York Times Magazine, 32-33, 122-126.

Habermas, J. (2008). Ach, Europa. Frankfurt am Main: Suhrkamp Verlag.

Harrison, J. S., \& Freeman, R. E. (2004). Special topic: Democracy in and around organizations. Is organizational democracy worth the effort? Academy of Management Executive, 18(3), 49-53.

Hart, O., \& Moore, J. (2000). Property rights and the nature of the firm. In N. J. Foss (Ed.), Theory of the firm (pp. 90-127). London: Routledge.

Held, D. (2004). Global covenant. Cambridge: Polity Press.

IMF. (2008). World leaders launch action plan to combat financial Crisis. IMF Survey Magazine. http://www.imf.org/external/pubs/ $\mathrm{ft} /$ survey/so/2008/new111508a.htm].

Immergut, E. (1992). The rules of the game: The logic of health policy-making in France, Switzerland and Sweden. In S. Steinmo, K. Thelen, \& F. Longstreth (Eds.), Structuring politics. Historical institutionalism in comparative analysis (pp. 57-89). Cambridge: Cambridge University Press.
Jensen, M. C., \& Meckling, W. H. (1976). Theory of the firmmanagerial behavior, agency costs, and ownership structure. Journal of Financial Economics, 3(4), 305-360.

Kaler, J. (2002). Responsibility, accountability and governance. Business Ethics: A European Review, 11(4), 327-334.

Kaul, I., Pedro, C., Le Goulven, K., \& Mendoza, R. U. (2003). Providing global public goods. Oxford: Oxford University Press.

Keohane, R. O. (2002). Global governance and democratic accountability. Miliband Lectures. London: London School of Economics.

Keohane, R. O., \& Nye, J. S. (1977). Power and interdependence: World politics in transition. Boston: Little Brown and Company.

Kerr, J. L. (2004). The limits of organizational democracy. Academy of Management Executive, 18(3), 81-95.

King, A. A., \& Lenox, M. J. (2000). Industry self-regulation without sanctions: The chemical industry's responsibility care program. The Academy of Management Journal, 43(4), 698-716.

Lahde, A. (2008). Goodbye... and think pot. Goodbye Letter. CNBC.COM.

Lehtimäki, H., \& J. Kujala. (2004). Strategising in multi-voiced business settings. Paper presented at EBRF 2004 conference Research Forum to Understand Business in Knowledge Society, Tampere, Finland, September 2004.

Matten, D., \& Crane, A. (2005). What is stakeholder democracy? Perspectives and issues. Business Ethics: A European Review, 14(1), 6-13.

Messner, D., \& Nuescheler, F. (2003). Das Konzept Global Governance-Stand und Perspektiven. INEF Report 67, Duisburg, pp. $1-52$.

Midttun, A. (2007). Corporate (social) responsibility as an arena for partnered governance: From the business to the public policy case. Paper presented at the EABIS annual colloquium, Barcelona, Spain, September 2007.

Milgrom, P., \& Roberts, J. (1992). Economics, organization and management. Englewood Cliffs, NJ: Prentice Hall.

Morgenthau, H. J. (1948). Politics among nations. Boston: McGraw Hill.

New York Times. (2008). Credit crisis-the essentials. New York: The New York Times.

Palazzo, G., \& Scherer, A. G. (2006). Corporate legitimacy as deliberation: A communicative framework. Journal of Business Ethics, 66(1), 71-88.

Phillips, R., Freeman, R. E., \& Wicks, A. C. (2003). What stakeholder theory is not. Business Ethics Quarterly, 13(4), 479-502.

Post, J. E., Preston, L. E., \& Sachs, S. (2002). Redefining the corporation: Stakeholder management and organizational wealth. Stanford: Stanford University Press.

Rasche, A. (2008). In search of global governance-the contribution of the United Nations Global Compact. Paper presented at the Academy of Management (AoM) annual meeting, Anaheim, CA, August 2008.

Rasche, A. (2009). A necessary supplement: What the United Nations global compact is and is not. Business \& Society. doi: 10.1177/0007650309332378).

Reinicke, W. H. (1997). Global public policy. Foreign Affairs, 76(6), $127-138$.

Roloff, J. (2008). Learning from multi-stakeholder networks: Issuefocussed stakeholder management. Journal of Business Ethics, 82(1), 233-250.

Rondinelli, D. A. (2002). Transnational corporations: International citizens or new sovereigns. Business \& Society Review, 107(4), 391-413.

Rosenau, J. N. (1995). Governance in the twenty-first century. Global Governance, 1, 13-43.

Rowley, T. J. (1997). Moving beyond dyadic ties-A network theory of stakeholder influences. Academy of Management Review, 22(4), 887-910. 
Sachs, S., Groth, H., \& Schmitt, R. (2010). The 'stakeholder view' approach: An untapped opportunity to manage corporate performance and wealth. Strategic Change, 19(3-4), 147-162.

Sachs, S., Rühli, E., \& Kern. I. (2011a). Stakeholders matter. London: Cambridge University Press.

Sachs, S., Schmitt, R., \& Perrin, I. (2011b). Stakeholder value creation system. Cambridge: Politeia.

Savage, G. T., Bunn, M. D., Gray, B., Xiao, Q. \& Wang, S. (2008). Stakeholder collaboration: Implications for stakeholder theory and practice. Paper presented at the annual meeting of the International Association for Business and Society (IABS), Tampere, Finland, June 2008.

Savage, G. T., Dunkin, J. W., \& Ford, D. M. (2004). Responding to a crisis: A stakeholder analysis of community health organizations. Journal of Health and Human Services Administration (JHHSA), 26(4), 383-414.

Schmitt, R. (2007). Dealing with an open stakeholder society: An investigation into the Camisea case. Bern: Haupt.

Spiegel-Online. (2008). Summit on financial markets and the world economy - full text of declaration. Spiegel Online International. http://www.spiegel.de/international/world/0,1518,590885,00. html.

Stiglitz, J. E. (2006). Making globalization work: The next steps to global justice. New York: Norton.

Stoker, G. (1998). Governance as theory: Five propositions. International Social Science Journal, 155, 17-28.

Stout, L. A. (2007). Why we should stop teaching. Dodge vs. Ford. UCLA School of Law, Law-Econ Research Paper No. 07-11.

Thompson, G., \& Driver, C. (2005). Stakeholder champions: How to internationalize the corporate social responsibility agenda. Business Ethics: A European Review, 14(1), 56-66.
Waddock, S., Bodwell, C., \& Graves, S. B. (2002). Responsibility: The new business imperative. Academy of Management Executive, 16(2), 132-148.

Waddock, S., \& Smith, N. (2000). Relationships: The real challenge of corporate global citizenship. Business \& Society Review, 105(1), 47-62.

Waltz, K. (1979). Theory of international politics. New York: Random House.

Wang, H. C., He, J., \& Mahoney, J. T. (2009). Firm-specific knowledge resources and competitive advantage: The roles of economic- and relationship-based employee governance mechanisms. Strategic Management Journal, 30(12), 1265-1285.

Williamson, O. E. (1989). Transaction cost economics. In R. Schmalensee \& R. Willig (Eds.), Handbook of industrial organization (pp. 135-182). Amsterdam: Elsevier Science.

Wilson, E. O. (1998). Consilience-the unity of knowledge. New York: Alfred A. Knopf.

Windsor, D. (2007). Toward a global theory of cross-border and multilevel corporate political activity. Business \& Society, 46, 253-278.

Windsor, D. (2008). Stakeholder dynamics. Paper presented at the annual meeting of the International Association for Business and Society (IABS), Tampere, Finland, June 2008.

Wolf, K. D. (2000). The new raison D'État: International cooperation against societies? In M. Albert, L. Brock, \& K. D. Wolf (Eds.), Civilizing world: Society and community beyond the state (pp. 119-132). Lanham: Rowman \& Littlefield.

Wolf, K. D. (2003). Normsetzung in internationalen Institutionen unter Mitwirkung privater Akteure? International Environmental Governance zwischen ILO, öffentlich-privaten Politiknetzwerken und Global Compact. In S. Von Schorlemer (Ed.), Praxishandbuch UNO: die Vereinten Nationen im Lichte globaler Herausforderungen (pp. 225-240). Berlin: Springer. 